\title{
Marcos Siscar
}

\section{Como você pensa a relação entre o tempo literá-} rio e o tempo histórico?

Creio que não se trata de via de mão única. Poesia e história têm trajetórias não coincidentes, mas que se cruzam constantemente. É importante reconhecer que em algum momento possam não coincidir, e que saibamos entender o modo como inevitavelmente se cruzam. $O$ poeta não é exatamente um antecipador da história, como se acreditou muito frequentemente; por outro lado, sua aventura não pode ser plenamente identificada com meras extensões da lógica ou do discurso da história. Tenho especial interesse pelo modo como a poesia dramatiza seu contemporâneo, muito mais do que o reflete, devolvendo-lhe as imagens de seus processos de exclusão, material ou simbólica.

Quais procedimentos sua obra adota diante de um mundo em que predominam a ação econômica e a espetacularização da arte?

A poesia não está fora das relações de "mercado", nem da concorrência entre discursos. A prova disso é que é frequentemente questionada, sequestrada ou chamada a responder questões. Sua inscrição nas relações de troca não é sempre opositora, nem especialmente contraditória, mas particularmente crítica, caracterizando um saber sobre a margem. Em suma, prefiro a poesia que se interessa pela margem, lugar em que se colocam em jogo as passagens contínuas e violentas do centro à margem (e vice-versa), onde está em jogo inclusive o que quer dizer "o centro", há tanto tempo ocupado por algo que é composto também pela ordem econômica. Tento perceber no meu corpo as marcas dessa violência, e fazer da poesia um espaço no qual o drama da "alienação" - em mais de um sentido - seja perceptível.

\section{Qual reflexão sua obra produz sobre a tradição} literária brasileira?

A tradição não pode ser senão relida, reelaborada, redimensionada e, deste modo, também reatualizada, "preservada". No caso da reflexão sobre a poesia brasileira, hoje, acho que é importante não apenas apontar a degradação dos valores modernistas, mas também reconhecer os efeitos colaterais de seu processo de legitimação: ao mesmo tempo que consolida um momento forte da nossa literatura, corre o risco de causar efeitos indesejados sobre a série literária. A falta de uma história da poesia dos últimos quarenta anos me parece significativa. Falta de recuo histórico? Falta de acontecimentos relevantes? De que ponto de vista? Acho que um dos desafios da poesia continua sendo aquele que a guiou desde o início da modernidade: $o$ de reinventar continuamente maneiras de herdar a poesia, de compreender quando e por que ela continua a fazer sentido mesmo acuada (acusando-se, inclusive, a si mesma) pela ideia de pobreza e de renúncia. E por que motivo essa deveria ser apenas tarefa para poetas?

\section{Como você pensa a forma literária?}

O sentido da forma não está dado. Esta é talvez uma das melhores heranças da modernidade: independente de o poeta trabalhar com elementos de forma "fixa" ou de forma "livre", o sentido da forma não está necessariamente definido. A forma precisa ser percebida, conquistada. A atenção para aquilo que está além, ou aquém, das palavras é um modo que posso usar para dizer a minha relação com a forma (ou com a "linguagem"). É preciso estar atento àquilo que quer se manifestar, quer ter lugar. Não me refiro à busca do novo, nem à emulação da originalidade do passado. A "irritação" drummondiana, para citar um exemplo conhecido de todos, quer dizer para mim não exatamente a mestria dialética 
do negativo, mas a tonalidade de quem se expõe às intempéries da forma e cuja grandeza reside na crise, justamente em fazer face àquilo que há de irresistivel e, portanto, de indomável na poesia. Quando se concretiza, a forma se determina, por exemplo, historicamente. Mas essa determinação não é previsível nem saturável.

Marcos Siscar (1964) é poeta, tradutor, professor e ensaista. Publicou Não se diz (7 Letras, 1999), Tome o seu café e saia (7 Letras, 2001), Metade da arte (7 Letras/ Cosac Naify, 2003) e O roubo do silêncio (7 Letras, 2006). Traduziu Os amores amarelos (Iluminuras, 1996), de Tristan Corbière; A rosa das línguas, com Paula Glenadel (Cosac Naify, 2004), de Michel Deguy; e Os animais do mundo, com Paula Glenadel (Cosac Naify, 2006), de Jacques Roubaud. 